\title{
Effects of Bispectral Index-controlled Use of Magnesium on Propofol Consumption and Sedation Level in Patients Undergoing Colonoscopy
}

\author{
KolonoskopiUygulanan Hastalarda, BispektralIndeksKontrollü, Magnezyum \\ Kullanımının Propofol Tüketimi ve Sedasyon Düzeyine Etkisi
}

\author{
Hamit YOLDAS $\odot$, Isa YILDIZ $\odot$, Ibrahim KARAGOZ $\bullet$, Mustafa SIT $\odot$, Muhammed Nur OGUN $\odot$, \\ Abdullah DEMIRHAN $\odot$, Murat BILGI $\odot$
}

Ethics Committee Approval: This study approved by the Abant Izzet Baysal University Clinical Studies Ethic Committee, 25 April 2017, 2017/99.

Conflict of interest: The authors declare that they have no conflict of interest.

Funding: None.

Informed Consent: Informed consent was taken from the patients enrolled in this study.
Cite as: Yoldas H, Yildiz I, Karagoz I, et al. Effects of Bispectral Index-controlled Use of Magnesium on Propofol Consumption and Sedation Level in Patients Undergoing Colonoscopy. Medeniyet Med J. 2019;34:380-6.

\begin{abstract}
Objective: The aim of this study is to investigate the effects of bispectral index-controlled use of magnesium on propofol consumption, periprocedural hemodynamic response and patient comfort.

Material: A total of 60 patients were enrolled in the study. In Group 1 (magnesium), a single dose $50 \mathrm{mg} / \mathrm{kg}$ magnesium sulfate diluted with $100 \mathrm{~mL} 0.9 \% \mathrm{NaCl}$ was administered $10 \mathrm{~min}$ utes before the beginning of the procedure. Initially bolus dose of $0.5 \mathrm{mg} / \mathrm{kg}$ propofol was applied. The maintenance dose of propofol was $60 \mathrm{mcg} / \mathrm{kg} / \mathrm{min}$. During the procedure, the propofol infusion was increased by titration until the bispectral index (BIS) value of 70 was achieved. In Group 2 (saline), $100 \mathrm{ml} 0.9 \% \mathrm{NaCl}$ was administered 10 minutes before the beginning of the procedure. The bolus and maintenance doses of propofol, and target BIS values were the same as those in Group 1.

Results: When BIS values were compared between the groups, the initial BIS values in the magnesium group (Group 1) were significantly higher than those of the saline group (Group 2) $(p<0.05)$. The time to reach BIS 70 was significantly shorter in the magnesium group $(p<0.05)$. Propofol consumption was greater in Group 2 than in Group $1(p<0.05)$. The time to reach BIS 70 was significantly shorter in Group 1 ( $p<0.05)$. No significant difference was found between the groups in terms of patient- and endoscopist-satisfaction $(p<0.05)$.

Conclusion: The use of magnesium in addition to propofol may be an efficient and reliable option to reduce the drug consumption during colonoscopic interventions.
\end{abstract}

Keywords: Bispectral index, colonoscopy, magnesium

Öz

Amac: Bu çalıșmanın amacı, bispektral indeks kontrollü magnezyum kullanımının propofol tüketimi, periprosedürel hemodinamik cevap ve hasta konforu üzerine etkilerini araştırmaktır. Yöntem: Calışmaya toplam 60 hasta dahil edildi. Grup I'de (magnezyum), işlem başlamadan 10 dakika önce tek bir doz $50 \mathrm{mg} / \mathrm{kg}$ magnezyum sülfat (100 mL \%0,9 NaCl ile seyreltilmiş) verildi. İşlem basslangıcında $0,5 \mathrm{mg} / \mathrm{kg}$ propofol bolusu uygulandı. Propofolün idame dozu $60 \mathrm{mcg} / \mathrm{kg} /$ dk. idi. İslem sırasında propofol infüzyonu bispektral indeks (BIS) değeri 70 olana kadar titrasyonla arttırıldı. Grup 2 de (salin), işlem başlamadan $10 \mathrm{dk}$. önce $100 \mathrm{ml} \% 0,9 \mathrm{NaCl}$ uygulandı. Propofol bolus ve idame dozları ve hedef BIS değerleri Grup 1'deki ile aynıdı.

Bulgular: BIS değerleri gruplar arasında karşılaştırıldığında, Magnezyum grubundaki (Grup 1) ilk BIS değerleri salin grubundan (Grup 2) anlamlı derecede yüksek idi $(p<0,05)$. BIS 70'e ulaşma süresi Magnezyum grubunda anlamlı derecede düşüktü (p 0,05). Propofol tüketimi Grup 2'de grup 1'den daha fazlaydı $(p<0,05)$. BIS 70'e ulaşma süresi Grup 1'de anlamlı derecede düşüktü $(p<0,05)$. Gruplar arasında hasta ve endoskopist memnuniyeti açısından anlamlı fark bulunmadı $(p<0,05)$.

Sonuç: Propofole ilaveten magnezyum kullanımı kolonoskopik müdahalelerde ilaç tüketimini azaltmak için etkili ve güvenilir bir seçenek olabilir.

Anahtar kelimeler: Bispektral indeks, kolonoskopi, magnezyum
Received: 25 September 2019

Accepted: 10 November 2019

Online First: 26 December 2019

\section{Corresponding Author:}

H. Yoldas

ORCID: 0000-0002-9265-1008 Bolu Abant Izzet Baysal University Faculty of Medicine, Department of Anesthesiology and Reanimation, Bolu, Turkey

yoldashamit@hotmail.com

I. Yildiz

ORCID: 0000-0001-7476-2217 Ibrahim Karagoz ORCID: 0000-0003-2954-4784 A. Demirhan ORCID: 0000-0003-4139-5080 M. Bilgi

ORCID: 0000-0002-9001-2309 Bolu Abant Izzet Baysal University Faculty of Medicine, Department of Anesthesiology and Reanimation, Bolu, Turkey

M. Sit

ORCID: 0000-0002-1571-6920

Bolu Abant Izzet Baysal University Faculty of Medicine,

Department of General Surgery, Bolu, Turkey

M.N. Ogun

ORCID: 0000-0001-5524-5767 Bolu Abant Izzet Baysal University Faculty of Medicine, Department of Neurology, Bolu, Turkey

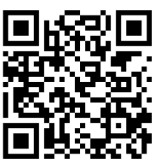


H. Yoldas et al. Effects of Bispectral Index-controlled Use of Magnesium on Propofol Consumption and Sedation Level in Patients Undergoing Colonoscopy

\section{INTRODUCTION}

Colonoscopy is one of the most commonly used methods in the diagnosis and treatment of colorectal diseases ${ }^{1}$. Moreover, in many cases, the procedure need to be repeated. Therefore, an effective sedation is necessary for patient comfort and ease of the procedure ${ }^{2,3}$. Propofol is one of the most commonly used sedative agents in endoscopic procedures ${ }^{4}$. It has no analgesic effect; however, it has dose-dependent sedative and amnesic effects. Propofol can be combined with different agents to reduce overuse ${ }^{5}$. Hypotension, respiratory depression, delayed awakening can be minimized by giving appropriate sedation doses ${ }^{6}$. Bispectral index (BIS) is often used to monitor depth of anesthesia and sedation. Bispectral analysis can reduce awareness during anesthesia. In addition, use of resources may be reduced as fewer drugs are required to produce amnesia. BIS values range from 0 to 100 (0, cortical silence; 100 awake, memory intact). A score between 40 and 60 is considered to indicate general anesthesia, 60 and 70 deep sedation, and 70 and 90 mild-to-moderate sedation ${ }^{7}$.

Magnesium, one of the most common cations in the body that is necessary for many physiological processes $^{8}$. Magnesium sulfate attenuates the hemodynamic response to tracheal intubation and significantly reduces consumption of anesthetic and analgesic drugs. Magnesium also significantly reduces BIS values ${ }^{9,10}$.

This prospective study was designed to assess the effects of magnesium sulfate on peri-procedural hemodynamics, patient- and endoscopist- satisfaction and propofol consumption when used as an adjuvant to propofol in colonoscopy.

\section{MATERIALS and METHODS}

This study was approved by the Abant Izzet Baysal University Clinical Studies Ethics Committee on April 25, 2017, 2017/99. Written and verbal informed consent was obtained from each participant after a full explanation of the study.

After obtaining approval from the institutional clinical research ethics committee, patients aged between 40 and 75 years were enrolled in this prospective randomized controlled study. Patients were scheduled to undergo outpatient colonoscopy under balanced propofol sedation in the Department of Gastroenterological Surgery of our hospital. Sixty patients with American Society of Anesthesiologists (ASA) status II-III were included in the study. Patients who were allergic to any of the drugs that would be used in the study, those with drug dependency, severe cardiac, renal, neurological, or liver diseases, patients who had taken any sedative drug within the previous 24 hours and those who refused participation were excluded from the study. Patients were equally randomized into two groups through the closed envelope method. The patients were informed about the method of anesthesia and evaluation scales (10-unit Verbal Rating Scale (VRS), Ramsay Sedation Score, and nausea/vomiting scale). As an oral purgative, sennoside $A+B$ calcium $(X M ®$; solution $250 \mathrm{~mL}$, Yenişehir Lab., Ankara, Turkey) was used in the pre-colonoscopy cleansing protocol. The enema containing sodium hydrogen phosphate and disodium hydrogen phosphate were administered through the rectal route (BT®; enema $210 \mathrm{~mL}$, Yenişehir Lab., Ankara, Turkey). Before the procedure, the patients were taken to the preparation room and 2-3 L/min oxygen was administered via nasal cannula. Prior to the induction of anesthesia, routine monitoring procedures (electrocardiography, heart rate, blood pressure and peripheral oxygen saturation) were performed and a 20 gauge intravenous line was established. An infusion of $0.9 \% \mathrm{NaCl}$ was administered at a rate of $5-8 \mathrm{ml} / \mathrm{kg} / \mathrm{min}$. BIS that uses processed electroencephalogram signals to measure the depth of sedation on a unitless scale from 0 to 100 was used to monitor the depth of anesthesia. A BIS sensor was attached to the middle and left side of the forehead and connected to a 
monitor (Bispectral Index A-2000, Aspect Medical Systems, Netherlands). Baseline BIS values were recorded before, during and after each procedure and the monitor rate was set at $15 \mathrm{sec}$. The BIS value for an effective sedation was considered as 70 .

The groups were determined as follows; Group 1 (magnesium sulfate group): magnesium sulfate (Magnezyum Sulfat 15\% Onfarma $10 \mathrm{ml} 10$ amp, Ankara, Turkey ) + propofol (Propofol Lipuro $1 \%$, B. Braun Irengun, Istanbul, Turkey), Group 2 (Saline group): $100 \mathrm{ml}$ 0.9\% NaCl + Propofol. In Group $1,50 \mathrm{mg} / \mathrm{kg}$ magnesium sulfate diluted with $100 \mathrm{~mL} 0.9 \% \mathrm{NaCl}$ solution was administered 10 minutes before the beginning of the procedure. At the beginning of the procedure a bolus dose of $0.5 \mathrm{mg} / \mathrm{kg}$ propofol was used. The maintenance dose of propofol was $60 \mathrm{mcg} / \mathrm{kg} /$ min. During the procedure, the propofol infusion was increased by titration until the BIS value of 70 was achieved. In Group 2, $100 \mathrm{ml} 0.9 \% \mathrm{NaCl}$ solution was administered (without magnesium) 10 minutes before the beginning of the procedure. The bolus and maintenance doses of propofol, and target BIS values were same with those in Group 1. Systolic blood pressure (SBP), diastolic blood pressure (DBP), mean arterial pressure (MAP), heart rate (HR), peripheral oxygen saturation $\left(\mathrm{SpO}_{2}\right)$, and BIS values were measured and recorded at 0., 5., 10., 15., 20. and 30. minutes before and during the intervention. Systolic blood pressure less than $90 \mathrm{mmHg}$ or a decrease in systolic pressure greater than $20 \%$ of baseline values, which was measured before the intervention was considered as hypotension. In the event of hypotension, intravenous fluid was administered and $5 \mathrm{mg}$ ephedrine hydrochloride (Ephedrine $0.05 \mathrm{~g} / \mathrm{ml}$, Osel, Istanbul, Turkey) was given, if no response was obtained to resuscitation with IV fluid administration. A heart rate below $50 \mathrm{bpm}$ was considered as bradycardia and IV atropine sulfate $0.5 \mathrm{mg}$ (Atropine sulfate injection Galen, Istanbul,Turkey) was given for the treatment of bradycardia. Oxygen (4 L/min) was delivered via face mask if $\mathrm{SpO}_{2}$ was below $95 \%$. If respiratory depression $\left(\mathrm{SPO}_{2}\right.$ less than $85 \%$ for longer than 60 seconds) occurred, the patients were treated with delivery of additional oxygen, and maneuvers as head extension and chin lift. If desaturation continued, mask ventilation was performed. Side effects such as hypotension, hypertension, tachycardia, bradycardia, desaturation, nausea, vomiting, pruritus, anesthesia and complications of the colonoscopic procedure were recorded during and after the intervention. Four-point nausea vomiting scale was used to assess nausea and vomiting. The pain rating was evaluated using a verbal rating scale [VRS- Very bad (0), Bad (1), Good (2), Very good (3)] at $30 \mathrm{~min}, 60 \mathrm{~min}$ and $2 \mathrm{~h}$ after the procedure. Grade of sedation was evaluated by Ramsay sedation scale after the intervention. Evaluation of patient-, and endoscopist- satisfaction [Very bad (0), Bad (1), Good (2), Very good (3)] was performed after the intervention. The total drug doses used in both groups were calculated and recorded after the procedure.

\section{Statistical analysis}

Statistical Package for Social Science (SPSS 23.0) program was used for statistical analysis. The descriptive variables; age, height, weight, heart rate (HR), mean arterial pressure (MAP), duration of intervention were expressed as mean \pm standard deviation. The Kolmogorov-Smirnov test was used to determine whether variables were normally distributed. Independent-Samples T-test was used to analyze normally distributed variables between groups. Analysis of variance (ANOVA) for repeated measures was used to compare BIS scores, MAP and HR values at pre-procedural, $1^{\text {st }}$, $5^{\text {th }}$ and $10^{\text {th }}$ minutes of propofol administration. Chi-square and Fisher's exact test were used for the analysis of categorical variables. A p value less than $0.05(p<0.05)$ was accepted as the cut-off value for statistical significance.

\section{RESULTS}

Sixty patients who were scheduled for elective colonoscopy were enrolled in the study. There 
H. Yoldas et al. Effects of Bispectral Index-controlled Use of Magnesium on Propofol Consumption and Sedation Level in Patients Undergoing Colonoscopy

was no significant difference in terms of demographic characteristics and duration of intervention between the two groups $(p<0.05$, Table 1$)$.

Table 1. The demographic characteristics of patients, time to reach BIS 70, propofol and magnesium consumption.

\begin{tabular}{|c|c|c|c|}
\hline & $\begin{array}{l}\text { Group I } \\
\text { (Magnesium) }\end{array}$ & $\begin{array}{l}\text { Group II } \\
\text { (Saline) }\end{array}$ & $\begin{array}{l}\mathbf{p} \\
\text { value }\end{array}$ \\
\hline Age & $58.2( \pm 11)$ & $58.5( \pm 11)$ & 0.908 \\
\hline Gender (M/F) & $13 / 17$ & $18 / 12$ & 0.301 \\
\hline Weight (kg) & $74.5( \pm 77)$ & $70.8( \pm 10)$ & 0.124 \\
\hline $\begin{array}{l}\text { Duration of intervention } \\
\text { (min) }\end{array}$ & $12.7( \pm 4.7)$ & $12.9( \pm 4.8)$ & 0.873 \\
\hline Reaching BIS 70 (sec) & $155( \pm 70)$ & $245( \pm 118)$ & 0.010 \\
\hline Propofol (mg) & $75.9( \pm 24)$ & $98.1( \pm 56)$ & 0.019 \\
\hline $\begin{array}{l}\text { Magnesium (mg) } \\
\text { (per patient) }\end{array}$ & $105.9( \pm 3.53)$ & & \\
\hline
\end{tabular}

The values were presented as mean ( \pm standard deviation)

Hypotension was not observed in groups. In Group 1, when the pre-procedural MAP value was compared with the $10^{\text {th }}$ minute MAP value a significant decrease was found $(p<0.05)$. In Group 2, MAP values at 1 st and 5 th minute were found to be significantly decreased compared to preprocedural values $(p<0.05$, Figure 1$)$. When the MAP values were compared, values at $10^{\text {th }}$ minute were significantly lower in Group $1(p<0.05)$.

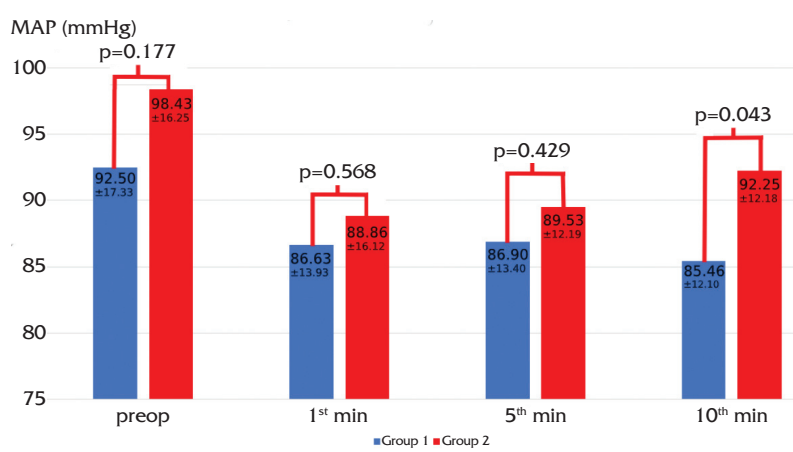

Figure 1. Comparison of the mean arterial pressure values between the groups MAP; Mean arterial pressure.

In both groups, the values of HR were compared with the pre-procedural values, and a significant decrease was observed at the $1^{\text {st }}, 5^{\text {th }}$ and $10^{\text {th }}$ minutes of the procedure $(p<0.05$, Figure 2$)$.

The dose of magnesium was $105.9 \mathrm{mg}$ per patient in Group 1. The mean amount of propofol consumption was $75.9 \pm 24 \mathrm{mg}$ in Group 1 and $98.1 \pm 56 \mathrm{mg}$ in Group 2. There was a significant difference between the two groups in terms of propofol consumption $(p<0.05$, Table 1$)$.

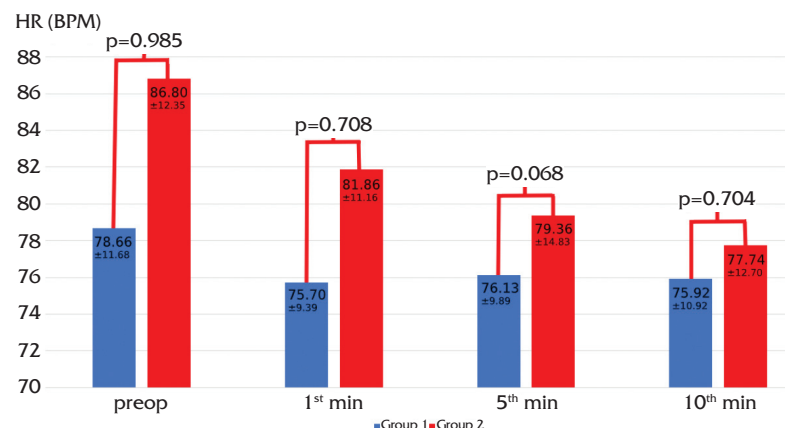

Figure 2. Comparison of the mean heart rate values between the groups HR; Heart rate, BPM; Beats per minute.

When BIS values were compared between the groups, the baseline BIS values in the $\mathrm{Mg} 2+$ group were significantly higher than that of the saline group ( $p<0.05$; Table 2, Fig 3 ). Nevertheless, the time to reach BIS 70 was significantly shorter in the $M g 2+$ group $(p<0.05)$ (Table 2$)$.

Table 2. Comparison of BIS values in the Magnesium and Saline groups.

BIS preop BIS $1^{\text {st }}$ min BIS $5^{\text {th }}$ min BIS $10^{\text {th }}$ min $($ mean \pm SD) $($ mean \pm SD) $($ mean \pm SD $)($ mean \pm SD $)$

\begin{tabular}{lllll}
$\begin{array}{l}\text { Group 1 } \\
\text { (magnesium) }\end{array}$ & $98.2 \pm 2.05$ & $75.3 \pm 6.72$ & $68.7 \pm 6.80$ & $66.6 \pm 6.80$ \\
$\begin{array}{l}\text { Group 2 } \\
\text { (saline) }\end{array}$ & $87.5 \pm 11.6$ & $73.8 \pm 9.91$ & $66.9 \pm 4.85$ & $67.2 \pm 4.60$ \\
\begin{tabular}{l} 
Total \\
\hline
\end{tabular} & $93.0 \pm 9.82$ & $74.6 \pm 8.39$ & $67.8 \pm 5.94$ & $66.9 \pm 5.78$ \\
\hline
\end{tabular}

The values were presented as mean ( \pm standard deviation)

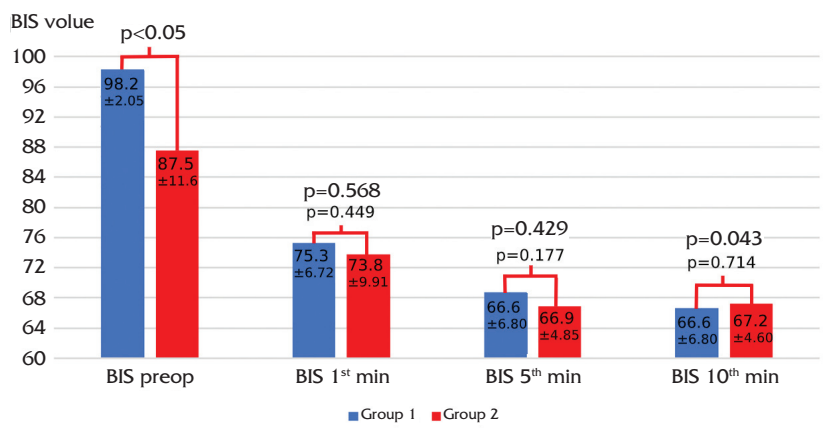

Figure 3. Comparison of the mean bispectral index values between the groups BIS; Bispectral index. 
The BIS values at $1^{\text {st }}, 5^{\text {th }}$ and $10^{\text {th }}$ min were significantly lower than the pre-procedural value in both groups $(p<0.05)$ (Figure 3$)$.

There was no significant difference between groups in terms of VRS scores, patient -, and endoscopist-satisfaction $(p<0.05)$. Desaturation, nausea and vomiting were not observed in any of the groups.

\section{DISCUSSION}

In the current study, we investigated the effect of magnesium sulfate as an adjuvant for sedation with propofol in colonoscopic procedures. When magnesium sulfate was given before the procedure, the BIS value rapidly decreased to sedation level and the amount of propofol consumption was significantly reduced.

Colonoscopic interventions under sedation have increased in recent years. Many drugs are being used alone (midazolam, diazepam, propofol, ketamine, droperidol, fentanyl, remifentanil) or in combination $^{11,12}$. No consensus has been reached for the optimal drug combination for endoscopy. One of the most commonly used anesthetic agents is propofol.

Many studies have shown that propofol is safe and effective $^{13,14}$. It has also been demonstrated that it shortens the induction period and increases satisfaction of endoscopists and patients ${ }^{15}$. However, it can lead to suppression of protective reflexes, especially in elderly patients, and significant depression in respiratory and cardiac parameters ${ }^{16-18}$.

It is possible to reduce the consumption and adverse side effects of a medication by combining with an adjuvant medication. The use of appropriate individual doses of propofol may improve health outcomes, reduce unnecessary costs and overuse of anesthesia which can be achieved by monitoring sedation levels ${ }^{19}$. Bispectral index (BIS) monitoring is an objective and reliable way to observe sedation levels. BIS is obtained from the electroencephalogram (EEG). Some hypnotic drugs such as ketamine and opioids are not suitable for BIS monitoring. BIS does not predict the physical response to hemodynamic stimulation and recovery time of the patient's consciousness $^{7,20}$.

The awareness of anesthesia can be reduced by monitoring depth of sedation with bispectral analysis. It can also decrease use of resources since fewer medications are used to provide amnesia. Moreover, it also provides easy recovery from anesthesia. The BIS value is obtained $15-30$ seconds earlier than the EEG data. Anesthetic concentration in the brain, level of analgesia and surgical stimulation may affect intraoperative BIS values. BIS values reflect the cerebral metabolic rate generated by hypnotic agents. Neurologic diseases, encephalopathy, cerebral ischemia, hypothermia, genetically determined low-voltage conditions, EMG and sedation can impact BIS values ${ }^{21}$. In the literature, it has been found that many drugs were used in combination with propofol in colonoscopy. However, the use of magnesium as an adjuvant has not been reported in previously published studies.

Studies have shown that perioperative magnesium may reduce the need for anesthetic use, the time required for BIS to reach 60 , and intraoperative analgesic consumption,10,22-24. Amer et al. ${ }^{10}$ reported that the use of magnesium in the pediatric general anesthesia may lead to significantly lower BIS values and reduction of time to reach values below BIS 60. Likewise, Olgun et al. ${ }^{25}$ found that perioperative use of magnesium sulfate reduces the consumption of propofol, desflurane and postoperative morphine requirement. Seyhan et al. ${ }^{26}$ have shown that a single dose of magnesium sulfate $(40 \mathrm{mg} / \mathrm{kg})$ reduces intraoperative propofol consumption by $13.5 \%$. In the present study, we also found that the use of magnesium sulfate before colonoscopy reduced propofol consumption. 
H. Yoldas et al. Effects of Bispectral Index-controlled Use of Magnesium on Propofol Consumption and Sedation Level in Patients Undergoing Colonoscopy

In a study investigating the effects of magnesium sulfate and clonidine on hemodynamic parameters and postoperative recovery, Altan et al. ${ }^{9}$ found that consumption of propofol, magnesium sulfate and clonidine significantly reduced propofol consumption and time to reach BIS 60 in both magnesium and clonidine groups. They reported that the need for fentanyl in the $\mathrm{Mg2}+$ group was not associated with any cardiovascular or hemodynamic side effect but the duration of extubation was longer and the recovery was slower. They also noted that the use of BIS may be a valuable tool for guiding the administration of propofol and BIS monitoring may reduce the propofol consumption. In the present study, we also found reduced propofol consumption in the $\mathrm{Mg} 2+$ group. Although the initial BIS values were significantly higher in the $M g 2+$ group, the time to reach BIS 70 was significantly shorter. Since the groups were randomized, the observed difference may be due to the initial effect of $\mathrm{Mg2+}$, which is used in the treatment of cerebral vasospasm. It has been shown that $\mathrm{Mg} 2+$ is well tolerated in humans. However, if serum concentrations are too high, it can lead to hypotension, bradycardia and later to more poorer outcomes ${ }^{8,26}$. In the current study, no side effects were observed.

\section{CONCLUSION}

The addition of magnesium sulfate to propofol was determined to be a safety measure ameliorating respiratory and hemodynamic complications during colonoscopy carried out under BIS monitoring. The addition of magnesium to propofol may be an alternative to the use of propofol alone for sedation in colonoscopic interventions in order to reduce the drug consumption.

\section{REREFENCES}

1. Shingina A, Ou G, Takach $O$, et al. Identification of factors associated with sedation tolerance in 5000 patients undergoing outpatient colonoscopy: Canadian tertiary center experience. World J Gastrointest Endosc. 2016;8(20):770-776. [CrossRef]

2. Demiraran Y, Tamer A, Korkut E, et al. Comparison of the sedative effects of dexmedetomidine and midazolam in cases undergoing colonoscopy. Endoskopy. 2009; 17:1822.

3. Kilgert B, Rybizki L, Grottke M, Neurath MF, Neumann H. Prospective long-term assessment of sedation-related adverse events and patient satisfaction for upper endoscopy and colonoscopy. Digestion. 2014;90:42-8. [CrossRef]

4. Sonnenberg A. Sedation in Colonoscopy. Gastroenterol Hepatol (N Y). 2016;12:327-9.

5. Regula J, Sokol-Kobielska E. Sedation in endoscopy: when and how. Best Pract Res Clin Gastroenterol. 2008;22(5):945-57. [CrossRef]

6. Toklu S, Iyilikci L, Gonen C, et al. Comparison of etomidate-remifentanil and propofol-remifentanil sedation in patients scheduled for colonoscopy. Eur J Anaesthesiol. 2009;26:370-6. [CrossRef]

7. Yu YH, Han DS, Kim HS, et al. Efficacy of bispectral index monitoring during balanced propofol sedation for colonoscopy: a prospective, randomized controlled trial. Dig Dis Sci. 2013;58:3576-83. [CrossRef]

8. Odom MJ, Zuckerman SL, Mocco J. The role of magnesium in the management of cerebral vasospasm. Neurol Res Int. 2013;2013:943914. [CrossRef]

9. Altan A, Turgut N, Yildiz F, Türkmen A, Ustün H. Effects of magnesium sulphate and clonidine on propofol consumption, haemodynamics and postoperative recovery. Br J Anaesth. 2005;94:438-41. [CrossRef]

10. Amer MM, Abdelaal Ahmed Mahmoud A, Abdelrahman Mohammed MK, Elsharawy AM, Ahmed DA, Farag EM. Effect of magnesium sulphate on bi-spectral index (BIS) values during general anesthesia in children. BMC Anesthesiol. 2015;15:126. [CrossRef]

11. Inadomi JM, Gunnarsson CL, Rizzo JA, Fang H. Projected increased growth rate of anesthesia professional-delivered sedation for colonoscopy and EGD in the United States: 2009 to 2015. Gastrointest Endosc. 2010;72:580-6. [CrossRef]

12. Bilgi M, Tekelioglu UY, Sit M, et al. Comparison of the effects of bispectral index-controlled use of remifentanil on propofol consumption and patient comfort in patients undergoing colonoscopy. Acta Gastroenterol Belg. 2015;78:314-8.

13. Sieg A; bng-Study-Group, Beck S, Scholl SG, et al. Safety analysis of endoscopist-directed propofol sedation: a prospective, national multicenter study of 24441 patients in German outpatient practices. J Gastroenterol Hepatol. 2014;29:517-23. [CrossRef]

14. Friedrich K, Stremmel W, Sieg A. Endoscopist-administered propofol sedation is safe - a prospective evaluation of 10,000 patients in an outpatient practice. J Gastrointestin Liver Dis. 2012;21:259-63.

15. Thornley P, Al Beshir M, Gregor J, Antoniou A, Khanna N. Efficiency and patient experience with propofol vs conventional sedation: A prospective study. World J Gastrointest Endosc. 2016;8:232-8. [CrossRef]

16. Hsu WH, Wang SS, Shih HY, et al. Low effect-site concentration of propofol target-controlled infusion reduces the risk of hypotension during endoscopy in a Taiwanese population. J Dig Dis. 2013;14:147-52. [CrossRef]

17. Ye L, Xiao X, Zhu L. The Comparison of Etomidate and Propofol Anesthesia in Patients Undergoing Gastrointestinal Endoscopy: A Systematic Review and Meta-Analysis. Surg Laparosc Endosc Percutan Tech. 2017;27:1-7. [CrossRef] 
18. Olofsen E, Boom M, Nieuwenhuijs D, et al. Modeling the non-steady state respiratory effects of remifentanil in awake and propofol-sedated healthy volunteers. Anesthesiology. 2010;112:1382-95. [CrossRef]

19. Inadomi JM. Editorial: Endoscopic Sedation: Who, Which, When? Am JGastroenterol. 2017;112:303-305. [CrossRef]

20. Johansen JW. Update on bispectral index monitoring. Best Pract Res Clin Anaesthesiol. 2006;20:81-99. [CrossRef]

21. AkıncıSB, Çelebioğlu B. Bispektral indeksmonitörizasyonu. J Turk Soc Intens Care. 2006;4:85-90.

22. Gupta K, Vohra V, Sood J. The role of magnesium as an adjuvant during general anaesthesia. Anaesthesia. 2006;61:1058-63. [CrossRef]

23. Lee DH, Kwon IC. Magnesium sulphate has beneficial effects as an adjuvant during general anaesthesia for Cae- sarean section. Br J Anaesth. 2009; 103:861-6. [CrossRef]

24. Khafagy HF, Ebied RS, Osman ES, Ali MZ, Samhan YM. Perioperative effects of various anesthetic adjuvants with TIVA guided by bispectral index. Korean J Anesthesiol. 2012;63:113-9. [CrossRef]

25. Olgun B, Oğuz G, Kaya $M$, et al. The effects of magnesium sulphate on desflurane requirement, early recovery and postoperative analgesia in laparascopic cholecystectomy. Magnes Res. 2012;25:72-8. [CrossRef]

26. Seyhan TO, Tugrul M, Sungur MO, et al. Effects of three different dose regimens of magnesium on propofol requirements, haemodynamic variables and postoperative pain relief in gynaecological surgery. $\mathrm{Br} J$ Anaesth. 2006;96:247-52. [CrossRef] 